\title{
PENGARUH APLIKASI BEBERAPA KONSENTRASI FORMULASI KERING Metarhizium anisopliae (Metsch.) Sorokin ISOLAT TEGINENENG TERHADAP MORTALITAS HAMA PENGISAP BUAH KAKAO (Helopeltis spp.)
}

\author{
Zaka Saputra, Purnomo*, Nur Yasin \& Lestari Wibowo \\ Jurusan Agroteknologi, Fakultas Pertanian Universitas Lampung \\ Jl.Prof. Soemantri Brodjonegoro, No.1, Bandar Lampung 35145 \\ E-mail: zakasaputra90@gmail.com \\ *Korespondensi, E-mail: purjomo@yahoo.com
}

\begin{abstract}
ABSTRAK
Salah satu musuh alami yang dapat digunakan untuk mengendalikan hama adalah jamur patogen serangga Metarhizium anisopliae. Pemanfaatan jamur entomopatogen sebagai bioinsektisida semakin berkembang. Teknologi produksi bioinsektisida dari jenis jamur entomopatogen dalam bentuk formulasi kering berkembang terus dan merupakan objek penelitian yang sangat menarik. Banyak keuntungan dari jamur entomopatogen yang dibuat dalam bentuk formulasi kering, diantaranya adalah dapat disimpan dalam jangka waktu yang cukup lama, praktis, dan mudah diaplikasikan. Penelitian ini bertujuan untuk mengetahui pengaruh aplikasi beberapa konsentrasi formulasi kering $M$. anisopliae isolat Tegineneng terhadap mortalitas hama pengisap buah kakao (Helopeltis spp.). Percobaan disusun dalam Rancangan Acak Kelompok yang terdiri atas 5 perlakuan. Pengelompokkan berdasarkan 3 kelompok waktu aplikasi yang berbeda. Perlakuan terdiri atas kontrol (tanpa aplikasi $M$. anisopliae), aplikasi formulasi kering M. anisopliae konsentrasi $5 \mathrm{~g} \mathrm{l}^{-1}$ air, aplikasi formulasi kering M. anisopliae konsentrasi $10 \mathrm{~g} \mathrm{l}^{-1}$ air, aplikasi formulasi kering $M$. anisopliae konsentrasi $15 \mathrm{~g} \mathrm{l}^{-1}$ air, dan aplikasi formulasi kering $M$. anisopliae konsentrasi $20 \mathrm{~g} \mathrm{l}^{-1}$ air. Hasil penelitian menunjukkan bahwa aplikasi formulasi kering jamur M. anisopliae konsentrasi $20 \mathrm{~g}^{-1}$ air menyebabkan mortalitas Helopeltis spp. sebesar 83,82\% berbeda nyata lebih tinggi dibandingkan perlakuan $5 \mathrm{~g} \mathrm{l}^{-1}$ dan $10 \mathrm{~g} \mathrm{l}^{-1}$, namun tidak berbeda nyata dibandingkan perlakuan $15 \mathrm{~g} \mathrm{l}^{-1}$.
\end{abstract}

Kata kunci : Formulasi kering, Helopeltis spp., Metarhizium anisopliae, mortalitas, musuh alami.

\section{PENDAHULUAN}

Kakao (Theobroma cacao L.) merupakan salah satu komoditas perkebunan yang mempunyai peran penting dalam perekonomian Indonesia. Tahun 2010 Indonesia merupakan pengekspor biji kakao terbesar ketiga dunia dengan produksi biji kering 550.000 ton setelah negara Pantai Gading (1.242.000 ton) dan Ghana dengan produksi 662.000 ton (ICCO, 2011 dalam Balittri, 2012). Pada tahun 2010, dari 1.475 .344 ha areal kakao Indonesia, sekitar 1.372.705 ha atau 93\% adalah kakao rakyat (Ditjenbun, 2010 dalam Balittri, 2012). Hal ini mengindikasikan peran penting kakao baik sebagai sumber lapangan kerja maupun pendapatan bagi petani.

Produktivitas kakao di Indonesia dan khususnya di Lampung sampai saat ini belum maksimal disebabkan adanya atau terkendala oleh organisme pengganggu tanaman (OPT). Salah satu OPT yang cukup penting pada tanaman kakao adalah Helopeltis spp. Helopeltis spp. menimbulkan kerusakan dengan cara menusuk dan mengisap cairan buah maupun tunas-tunas muda. Serangan pada buah muda menyebabkan matinya buah tersebut, sedangkan serangan pada buah berumur sedang mengakibatkan terbentuknya buah abnormal. Akibatnya, daya hasil dan mutu kakao menurun. Serangan berat $H$. antonii dalam satu musim dapat menurunkan daya hasil rata-rata $42 \%$ selama tiga tahun berturut-turut (Wardoyo, 1988 dalam Atmadja, 2003).

Pengendalian Helopeltis spp. perlu dilakukan untuk mencegah kehilangan hasil produksi kakao. Pengendalian yang baik pada saat ini adalah pengendalian yang aman dan ramah lingkungan. Menurut Junianto (2000 dalam Prayogo dan Suharsono, 2005) penggunaan musuh alami seperti jamur entomopatogen memenuhi kriteria pengendalian yang aman dan ramah lingkungan.

Beberapa jenis jamur entomopatogen yang telah dimanfaatkan untuk mengendalikan hama tanaman perkebunan dan sayuran adalah Metarhizium anisopliae, Beauveria bassiana, Paecilomyces sp., Verticillium sp., dan Spicaria sp. (Gabriel dan Riyanto, 1989; Pendland dan Boucias, 1998 dalam Prayogo et al., 2005). M. anisopliae telah lama digunakan sebagai agensia hayati dan dapat menginfeksi beberapa jenis serangga, antara lain dari ordo Coleoptera, Lepidoptera, 
Homoptera, Hemiptera, dan Isoptera (Gabriel dan Riyanto, 1989; Strack, 2003 dalam Prayogo et al., 2005)

Pemanfaatan jamur entomopatogen sebagai bioinsektisida semakin berkembang. Hal ini terjadi karena bioinsektisida diharapkan dapat mengurangi laju dampak negatif dari penggunaan pestisida yang selama ini dilakukan. Teknologi produksi bioinsektisida dari jenis jamur entomopatogen dalam bentuk formulasi kering berkembang terus dan merupakan objek penelitian yang sangat menarik. Banyak keuntungan dari jamur entomopatogen yang dibuat dalam bentuk formulasi kering, diantaranya adalah dapat disimpan dalam jangka waktu yang cukup lama, praktis, dan mudah diaplikasikan (Suwahyono, 2010).

Helopeltis spp. tergolong dalam ordo Hemiptera dan jamur Metarhizium spp. dapat berperan sebagai bioinsektisida dalam pengendali hayati untuk mengendalikan Helopeltis spp. Oleh karena itu maka perlu dibuat formulasi kering dari jamur M. anisopliae isolat Tegineneng supaya mudah dalam aplikasinya dan dapat digunakan untuk mengendalikan dan mematikan hama pengisap buah kakao (Helopeltis spp.).

Tujuan penelitian ini adalah untuk mengetahui pengaruh aplikasi beberapa konsentrasi formulasi kering $M$. anisopliae isolat Tegineneng terhadap mortalitas hama pengisap buah kakao (Helopeltis spp.).

\section{METODE PENELITIAN}

Penelitian ini dilaksanakan pada bulan September 2012 sampai dengan Februari 2013, di Laboratorium Hama Tumbuhan Fakultas Pertanian Universitas Lampung. Percobaan disusun dalam Rancangan Acak Kelompok yang terdiri atas 5 perlakuan. Setiap perlakuan terdiri atas 3 kelompok waktu aplikasi yang berbeda. Sehingga jumlahnya terdiri dari 15 satu satuan percobaan. Setiap satu satuan percobaan terdiri atas 20 ekor serangga uji yang diaplikasi. Perlakuan terdiri atas kontrol (tanpa aplikasi M. anisopliae) (P0), aplikasi formulasi kering $M$. anisopliae konsentrasi $5 \mathrm{~g} \mathrm{l}^{-1}$ air (P1), aplikasi formulasi kering M. anisopliae konsentrasi $10 \mathrm{~g}^{-1}$ air (P2), aplikasi formulasi kering M. anisopliae konsentrasi $15 \mathrm{~g} \mathrm{l}^{-1}$ air (P3), dan aplikasi formulasi kering M. anisopliae konsentrasi $20 \mathrm{~g} \mathrm{l}^{-1}$ air (P4). Data yang didapatkan kemudian dianalisis menggunakan sidik ragam dan dilanjutkan dengan Uji Beda Nyata Terkecil (BNT) dengan taraf nyata 5\% kemudian dilakukan analisis probit untuk menentukan $\mathrm{LC}_{50}$.

Pembiakan serangga ini dilakukan di laboratorium, yaitu dengan menggunakan inang alternatif (mentimun). Sebelum pembiakan terlebih dahulu dilakukan pencarian indukan serangga Helopeltis spp. Indukan serangga terdiri atas imago dan nimfa Helopeltis spp. yang diambil dari lapangan. Indukan imago dan nimfa dipisahkan dan dimasukkan ke dalam stoples plastik berdiameter $16 \mathrm{~cm}$ dengan tinggi $17 \mathrm{~cm}$ yang sudah ada pakan mentimun di dalamnya. Stoples plastik ditutup menggunakan kain sifon yang diikat menggunakan karet gelang. Setiap stoples diisi \pm 20 ekor serangga dan 2 buah mentimun. Pakan diganti setiap 2-3 hari sekali. Setelah imago bertelur, mentimun yang digunakan sebagai media bertelur dipisahkan dan ditempatkan pada stoples yang baru sampai \pm 4 mentimun. Stoples ditutup dan diberi label tanggal. Setelah telur menetas, nimfa dipindahkan ke dalam stoples yang baru dan diberi mentimun yang masih segar. Begitu seterusnya sampai diperoleh jumlah serangga yang diperlukan.

Sabouraud Dextrose Agar merupakan media yang mengandung pepton di dalamnya. Satu liter air destilata ini dikomposisikan dari $40 \mathrm{~g}$ dextrose, $5 \mathrm{~g}$ pepton, $5 \mathrm{~g}$ kasein, dan $15 \mathrm{~g}$ agar. Semua larutan dimasukkan ke dalam tabung erlenmeyer kemudian ditutup menggunakan alumunium foil, dikencangkan dengan karet gelang dan dibungkus plastik tahan panas. Selanjutnya larutan SDA diautoklaf selama 2 jam pada suhu $121^{\circ} \mathrm{C}$. Setelah itu erlenmeyer diangkat dan didiamkan sebentar supaya sedikit lebih dingin, kemudian larutan SDA dituangkan ke masing-masing cawan petri dalam ruangan steril (Laminar Air Flow). Setelah SDA mengeras, kemudian dilakukan isolasi jamur $M$. anisopliae yang berasal dari Tegineneng. Kemudian diinkubasi selama 1 bulan. Setelah itu isolat siap digunakan untuk pengujian lebih lanjut.

Beras dicuci sampai bersih, kemudian disiram dengan air mendidih. Beras dikukus hingga setengah matang (10 menit), kemudian diangkat dan dikeringanginkan. Sekitar $100 \mathrm{~g}$ beras dimasukkan dalam kantong plastik. Beras dipadatkan dan diposisikan pada bagian bawah plastik. Bagian atas plastik yang tidak terisi dirapikan, digulung, dan diikat dengan karet gelang. Beras disterilkan dengan autoklaf pada suhu $120^{\circ} \mathrm{C}$, tekanan 1 atm,selama 15 menit. Beras diangkat dan dikeringanginkan, kemudian diinokulasi dengan isolat $M$. anisopliae, diinkubasi selama 2 minggu.

Dalam penelitian ini, pembuatan formulasi kering M. anisopliae mengacu pada Purnomo et al.(2012). Pembuatan formulasi kering dimulai dengan mengeringkan jamur $M$. anisopliae yang tumbuh pada media beras. Pengeringan dilakukan dengan pengeringan dingin. Pengeringan dingin dilakukan di dalam lemari es pada suhu $5^{\circ} \mathrm{C}$ selama 12 hari. Setelah kering jamur $M$. anisopliae dihaluskan dengan cara diblender lalu diayak sehingga menjadi tepung biomassa spora $M$. anisopliae. Bahan pembawa seperti tepung jagung, 
kaolin, dan zeolit juga disterilkan dengan oven pada suhu $80^{\circ} \mathrm{C}$ selama $2 \mathrm{jam}$. Setelah itu tepung biomassa spora M. anisopliae dicampur dengan bahan pembawa (Tabel 1).

Untuk mengetahui kerapatan spora dari tepung biomassa spora maka diambil $1 \mathrm{~g}$ tepung biomassa spora dan dimasukkan ke dalam $10 \mathrm{ml}$ aquades, dihomogenkan dengan rotamixer dan diencerkan hingga $10^{-3}$, lalu dihitung jumlah sporanya dengan bantuan alat Haemocytometer. Hasil penghitungan kerapatan spora menunjukkan bahwa jamur $M$. anisopliae isolat Tegineneng memiliki kerapatan spora 3,1 x $10^{6}$.

Sebelum ditentukan berapa konsentrasi yang akan digunakan untuk pengujian, terlebih dahulu dilakukan uji pendahuluan. Pada uji pendahuluan digunakan konsentrasi $10 \mathrm{~g} \mathrm{l}^{-1}$ dan $15 \mathrm{~g} \mathrm{l}^{-1}$. Serangga uji berjumlah 10 ekor per satu satuan percobaan. Konsentrasi $10 \mathrm{~g} \mathrm{l}$ ${ }^{1}$ menyebabkan kematian 9 ekor imago Helopeltis spp. dan konsentrasi $15 \mathrm{~g} \mathrm{l}^{-1}$ menyebabkan kematian 10 ekor imago Helopeltis spp. Selanjutnya pada pengujian ditentukan 5 perlakuan dengan masing-masing konsentrasi yaitu $5 \mathrm{~g} \mathrm{l}^{-1}, 10 \mathrm{~g} \mathrm{l}^{-1}, 15 \mathrm{~g} \mathrm{l}^{-1}, 20 \mathrm{~g} \mathrm{l}^{-1}$, dan kontrol. Masing- masing konsentrasi M. anisopliae yang akan digunakan dicampur dengan air sebanyak 1 liter, kemudian ditambah bahan perata perekat Indostick sebanyak $2 \mathrm{ml}$.

Aplikasi formulasi kering M. anisopliae dilakukan dengan cara memasukkan serangga uji Helopeltis spp. yang terdiri dari 20 ekor imago per satu satuan percobaan ke dalam botol air mineral yang dipotong bagian atas dan bawahnya lalu pada bagian bawah botol ditutup dengan kain strimin dan diikat dengan karet gelang. Hal ini dilakukan agar saat dilakukan penyemprotan serangga uji tidak terendam larutan formulasi kering. Selanjutnya suspensi disemprotkan menggunakan handsprayer sesuai dengan tingkat konsentrasi yang telah ditentukan. Setelah disemprot serangga uji dimasukkan kembali ke dalam toples dan diberi pakan mentimun. Pengamatan jumlah Helopeltis spp. yang mati akibat terinfeksi jamur $M$. anisopliae dilakukan setiap 24 jam sekali selama 10 hari setelah aplikasi. Menurut Rustama et al. (2008) persentase mortalitas (kematian) serangga dapat dihitung menggunakan rumus seperti berikut:

$$
M=\frac{n}{N} \times 100 \%
$$

dengan $\mathrm{M}$ adalah mortalitas serangga (\%), $\mathrm{n}$ adalah serangga yang mati (ekor), dan $\mathrm{N}$ adalah jumlah serangga yang diuji (ekor).

Apabila terdapat kematian Helopeltis spp. pada kontrol maka persentase kematian terkoreksi dihitung berdasarkan rumus Abbot (1925 dalam Hasinu, 2009).

$$
\mathrm{Pt}=\frac{(\mathrm{Po}-\mathrm{Pc})}{(100-\mathrm{Pc})} \times 100
$$

dengan Pt adalah \% kematian terkoreksi, Po adalah \% kematian pada perlakuan, dan Pc adalah \% kematian pada kontrol. Selain menghitung persentase mortalitas Helopeltis spp. dilakukan juga penghitungan periode letal. Periode letal adalah banyaknya waktu yang dihitung dari sejak aplikasi sampai serangga uji mengalami kematian. Periode letal dapat dihitung dengan rumus (Susilo et al., 1993 dalam Indriyati, 2009) sebagai berikut:

$$
\text { Periode Letal }(\mathrm{T})=\left[\sum\left(\mathrm{H}_{\mathrm{i}} \times \mathrm{M}_{\mathrm{i}}\right)\right] /\left[\sum\left(\mathrm{M}_{\mathrm{i}}\right)\right]
$$

dengan $\mathrm{F}$ adalah periode letal, Hi adalah hari ke-i, dan Mi adalah jumlah serangga mati (ekor) karena terinfeksi jamur M. anisopliae pada hari ke- $\mathrm{i}$

\section{HASIL DAN PEMBAHASAN}

Hasil percobaan menunjukkan bahwa aplikasi formulasi kering jamur M. anisopliae isolat Tegineneng secara nyata menyebabkan mortalitas Helopeltis spp. pada pengamatan 1 hsa sampai 10 hsa (Tabel 2).

Pada Tabel 2 terlihat bahwa pada 1 hsa, kematian Helopeltis spp. tertinggi $(8,33 \%)$ terdapat pada perlakuan P3, tidak berbeda nyata dengan perlakuan P2 dan P4 namun berbeda nyata dengan perlakuan P0 dan P1. Pada pengamatan 4 hsa kematian Helopeltis spp. tertinggi terdapat pada P3 $(40,79 \%)$ berbeda nyata dengan $\mathrm{P} 1$, namun tidak berbeda nyata dengan $\mathrm{P} 2$ dan P4. Pada pengamatan 6 hsa perlakuan $20 \mathrm{~g} \mathrm{l}^{-1}$ (P4)

Tabel 1. Komposisi formulasi kering jamur M. anisopliae

\begin{tabular}{lc}
\hline Bahan & Jumlah $(\mathrm{g})$ \\
\hline Tepung biomassa spora M. anisopliae & 40 \\
Kaolin & 20 \\
Zeolit & 20 \\
Tepung jagung & 20 \\
\hline Total & 100 \\
\hline
\end{tabular}


Tabel 2. Nilai tengah mortalitas terkoreksi Helopeltis spp.

\begin{tabular}{ccccccccccc}
\hline & \multicolumn{8}{c}{ Mortalitas (\%) terkoreksi Helopeltis spp. pada } \\
\cline { 2 - 10 } Perlakuan & 1 hsa & 2 hsa & 8 hsa & 8 hsa & 5 hsa & 6 hsa & 7 hsa & 8 hsa & 9 hsa & 10 hsa \\
\cline { 2 - 11 } & 0,00 & 0,00 & 0,00 & 0,00 & 0,00 & 0,00 & 0,00 & 0,00 & 0,00 & 0,00 \\
P0 & $\mathrm{a}$ & $\mathrm{a}$ & $\mathrm{a}$ & $\mathrm{a}$ & $\mathrm{a}$ & $\mathrm{a}$ & $\mathrm{a}$ & $\mathrm{a}$ & $\mathrm{a}$ & $\mathrm{a}$ \\
& 0,00 & 10,00 & 16,66 & 28,77 & 36,05 & 41,90 & 49,90 & 47,67 & 47,67 & 46,81 \\
$\mathrm{P} 1$ & $\mathrm{a}$ & $\mathrm{ab}$ & $\mathrm{b}$ & $\mathrm{b}$ & $\mathrm{b}$ & $\mathrm{b}$ & $\mathrm{b}$ & $\mathrm{b}$ & $\mathrm{b}$ & $\mathrm{b}$ \\
& 5,00 & 16,66 & 26,66 & 33,95 & 44,82 & 47,36 & 53,40 & 63,84 & 63,84 & 65,19 \\
P2 & $\mathrm{ab}$ & $\mathrm{b}$ & $\mathrm{b}$ & $\mathrm{bc}$ & $\mathrm{b}$ & $\mathrm{bc}$ & $\mathrm{b}$ & $\mathrm{c}$ & $\mathrm{c}$ & $\mathrm{c}$ \\
& 8,33 & 15,00 & 30,00 & 40,79 & 41,22 & 52,63 & 63,40 & 69,85 & 71,81 & 73,52 \\
P3 & $\mathrm{b}$ & $\mathrm{b}$ & $\mathrm{b}$ & $\mathrm{c}$ & $\mathrm{b}$ & $\mathrm{c}$ & $\mathrm{bc}$ & $\mathrm{cd}$ & $\mathrm{cd}$ & $\mathrm{cd}$ \\
& 5,00 & 15,00 & 25,00 & 33,77 & 50,00 & 68,46 & 72,26 & 79,90 & 83,94 & 83,82 \\
P4 & $\mathrm{ab}$ & $\mathrm{b}$ & $\mathrm{b}$ & $\mathrm{bc}$ & $\mathrm{b}$ & $\mathrm{d}$ & $\mathrm{c}$ & $\mathrm{d}$ & $\mathrm{d}$ & $\mathrm{d}$ \\
\hline \multirow{2}{*}{ F hit } & 4,27 & 5,06 & 6,00 & 19,98 & 13,38 & 67,47 & 29,58 & 61,47 & 61,56 & 63,50 \\
& $*$ & $*$ & $*$ & $* *$ & $* *$ & $* *$ & $* *$ & $* *$ & $* *$ & $* *$ \\
\hline \multirow{2}{*}{ BNT } & 5,70 & 10,38 & 16,03 & 11,62 & 17,73 & 10,13 & 16,85 & 13,08 & 13,57 & 13,51 \\
\hline
\end{tabular}

Keterangan: Angka sekolom yang diikuti dengan huruf yang berbeda menunjukkan nilai tengah yang berbeda nyata pada uji BNT $\alpha=0,05 . \mathrm{P} 0=$ Kontrol (tanpa aplikasi formulasi kering $M$. anisopliae), $\mathrm{P} 1=$ Aplikasi formulasi kering $M$. anisopliae konsentrasi $5 \mathrm{~g} \mathrm{l}^{-1}$ air, $\mathrm{P} 2=$ Aplikasi formulasi kering M. anisopliae konsentrasi $10 \mathrm{~g} \mathrm{l}^{-1}$ air, P3= Aplikasi formulasi kering $M$. anisopliae konsentrasi $15 \mathrm{~g} \mathrm{l}^{-1}$ air, dan P4 = Aplikasi formulasi kering M. anisopliae konsentrasi $20 \mathrm{~g} \mathrm{l}^{-1}$ air.

menyebabkan mortalitas tertinggi $(68,46 \%)$ dan berbeda nyata dibandingkan perlakuan $5 \mathrm{~g} \mathrm{l}^{-1}, 10 \mathrm{~g} \mathrm{l}^{-1}$, dan $15 \mathrm{gl}^{-}$ 1. Pada pengamatan 7 hsa kematian Helopeltis spp. tertinggi terdapat pada perlakuan $20 \mathrm{~g} \mathrm{l}^{-1}(72,26 \%)$ berbeda nyata dengan perlakuan $5 \mathrm{~g} \mathrm{l}^{-1}$ dan $10 \mathrm{~g} \mathrm{l}^{-1}$, namun tidak berbeda nyata dengan perlakuan $15 \mathrm{~g} \mathrm{l}^{-1}$. Pada pengamatan 10 hsa (Tabel 2) mortalitas Helopeltis spp. tertinggi terdapat pada perlakuan $20 \mathrm{~g}^{-1}(83,82 \%)$ yang tidak berbeda nyata dengan perlakuan $15 \mathrm{~g} \mathrm{l}^{-1}$, namun berbeda nyata lebih tinggi dibandingkan perlakuan $5 \mathrm{~g} \mathrm{l}^{-1}$ dan $10 \mathrm{~g} \mathrm{l}^{-1}$.

Secara umum, data (Tabel 2) menunjukkan bahwa semakin tinggi konsentrasi formulasi kering $M$. anisopliae maka semakin tinggi pula persentase mortalitas Helopeltis spp. Hal ini serupa dengan pernyataan Ferron (1981 dalam Heriyanto dan Suharno, 2008) yang menyatakan keberhasilan penggunaan jamur entomopatogen dalam pengendalian hama antara lain ditentukan oleh konsentrasi/kepadatan spora, semakin tinggi konsentrasi maka semakin banyak spora yang terkandung di dalamnya. Jumlah spora yang banyak itu akan menyebabkan peluang jamur dalam mematikan serangga juga makin cepat.

Helopeltis spp. yang telah diaplikasi dengan $M$. anisopliae tampak terlihat pasif, tidak aktif makan, dan akhirnya mengalami kematian. Menurut (Bateman et al., 1997; Feron, 1981) dalam Nuraida dan Hasyim (2009) infeksi jamur entomopatogen pada serangga terjadi akibat adanya kontak konidia. Konidia mempenetrasi kutikula serangga dengan bantuan enzim pengurai. Enzim tersebut, antara lain kitinase, lipase, amilase, fosfatase, esterase, dan protease serta racun dari golongan destruksin, beauverisin, dan mikotoksin yang menghambat produksi energi dan protein. Akibat gangguan toksin tersebut, gerakan serangga menjadi lambat dan akhirnya mati. Setelah serangga mati, jamur membentuk klamidiospor di dalam tubuh serangga (Tanada dan Kaya, 1993; Freimoser et al., 2003 dalam Nuraida dan Hasyim, 2009).

Pendugaan nilai toksisitas insektisida terhadap serangga hama diukur dengan nilai $\mathrm{LC}_{50}$, yaitu suatu konsentrasi atau dosis yang dapat menyebabkan kematian 50\% serangga hama yang diuji (Moekasan, 1993 dalam Negara, 2003). Untuk mengetahui daya racun formulasi kering $M$. anisopliae terhadap mortalitas Helopeltis spp. digunakan analisis probit. Berdasarkan hasil analisis probit pada beberapa taraf konsentrasi formulasi kering jamur $M$. anisopliae terhadap data pengamatan 10 hsa menunjukkan nilai $\mathrm{LC}_{50}$ sebesar 5,70 $\mathrm{g} \mathrm{l}^{-1}$. Nilai tersebut menunjukkan konsentrasi $M$. anisopliae yang menyebabkan kematian $50 \%$ serangga uji adalah $5,70 \mathrm{~g} \mathrm{l}^{-1} \pm 1,82 \mathrm{~g} \mathrm{l}^{-1}$.

Periode letal adalah banyaknya waktu yang dihitung dari sejak aplikasi sampai serangga uji mengalami kematian. Tabel 3 menunjukkan bahwa periode letal dari perlakuan P4 (20 $\left.\mathrm{g} \mathrm{l}^{-1}\right)$ terhadap Helopeltis spp. adalah 
Tabel 3. Periode letal jamur M. anisopliae isolat dari Tegineneng

\begin{tabular}{lc}
\hline Perlakuan & Periode letal (hari) \\
\hline P1 & $4,52 \mathrm{a}$ \\
P2 & $4,68 \mathrm{a}$ \\
P3 & $4,76 \mathrm{a}$ \\
P4 & $4,81 \mathrm{a}$ \\
\hline BNT & 0,90 \\
\hline
\end{tabular}

Keterangan: Nilai tengah yang diikuti dengan huruf yang sama dinyatakan tidak berbeda nyata pada taraf uji BNT $\alpha=0,05$. P1 $=$ Aplikasi formulasi kering $M$. anisopliae konsentrasi $5 \mathrm{~g} \mathrm{l}^{-1}$ air, $\mathrm{P} 2=$ Aplikasi formulasi kering M. anisopliae konsentrasi $10 \mathrm{~g}^{-1}$ air, $\mathrm{P} 3=$ Aplikasi formulasi kering $M$. anisopliae konsentrasi $15 \mathrm{~g} \mathrm{l}^{-1}$ air, dan P4 = Aplikasi formulasi kering M. anisopliae konsentrasi $20 \mathrm{~g} \mathrm{l}^{-1}$ air.

4,81 hari. Nilai ini menunjukkan bahwa M. anisopliae mampu menimbulkan kematian pada Helopeltis spp. rata-rata pada hari ke 4,81. Perlakuan $5 \mathrm{~g} \mathrm{l}^{-1}$ dan $10 \mathrm{~g} \mathrm{l}^{-}$ ${ }^{1}$ memiliki periode letal yaitu 4,52 dan 4,68 hari. Perlakuan P3 (15 $\left.\mathrm{g} \mathrm{l}^{-1}\right)$ memiliki periode letal 4,76 hari. Tabel 3 menunjukkan periode letal $M$. anisopliae dengan konsentrasi $20 \mathrm{~g} \mathrm{l}^{-1}(\mathrm{P} 4)$ tidak berbeda nyata dengan periode letal perlakuan $5 \mathrm{~g} \mathrm{l}^{-1}, 10 \mathrm{~g} \mathrm{l}^{-1}$, dan $15 \mathrm{~g} \mathrm{l}^{-1}$.

Dari hasil penelitian ini terlihat bahwa aplikasi formulasi kering $M$. anisopliae mampu mematikan Helopeltis spp. dan selanjutnya formulasi kering $M$. anisopliae ini dapat digunakan untuk aplikasi di lapang pada tingkat petani untuk mengendalikan populasi hama pengisap buah kakao (Helopeltis spp.).

\section{KESIMPULAN}

Aplikasi formulasi kering jamur $M$. anisopliae konsentrasi $20 \mathrm{~g} \mathrm{l}^{-1}$ air menyebabkan mortalitas Helopeltis spp. sebesar $83,82 \%$ berbeda nyata lebih tinggi dibandingkan perlakuan $5 \mathrm{~g} \mathrm{gl}^{-1}$ dan $10 \mathrm{gl}^{-1}$, namun tidak berbeda nyata dibandingkan perlakuan $15 \mathrm{~g} / \mathrm{l}$. Daya racun formulasi kering $M$. anisopliae isolat Tegineneng terhadap mortalitas Helopeltis spp. ditunjukkan dengan nilai $\mathrm{LC}_{50}$ pada 10 hsa sebesar 5,70 $\mathrm{g} \mathrm{l}^{-1} \pm 1,82 \mathrm{~g} \mathrm{l}^{-1}$. Periode letal jamur $M$. anisopliae isolat Tegineneng terhadap mortalitas Helopeltis spp. pada perlakuan $5 \mathrm{~g}$ $\mathrm{l}^{-1}$ sampai dengan $20 \mathrm{~g}^{-1}$ tidak berbeda nyata berkisar antara 4,52 hari sampai 4,81 hari setelah aplikasi.

\section{DAFTAR PUSTAKA}

Negara. A. 2003. Penggunaan analisis probit untuk pendugaan tingkat kepekaan populasi Spodoptera exigua terhadap deltametrin di daerah istimewa Yogyakarta. Informatika Pertanian. 12(1): 1-9.
Atmadja, W.R. 2003. Status Helopeltis antonii sebagai hama pada beberapa tanaman perkebunan dan pengendaliannya. J. Litbang Pertanian 2(2):5763.

Balittri. 2012. Status komoditas kakao. http:// balittri.litbang.deptan.go.id/index.php/komoditas/ 66-kakao/101-status-komoditas-dan-daerahpengembangannya. Diakses pada tanggal 17 Agustus 2012.

Hasinu. 2009. Isolasi dan uji patogenitas Bacillus thuringensis terhadap Crocidolomia binotalis Zell. (Lepidoptera:Pyralidae). J. Budidaya Pertanian. 5(2): 84-88.

Heriyanto, dan Suharno. 2008. Studi patogenitas Metarhizium anisopliae (metch.) Sor hasil perbanyakan medium cair alami terhadap larva Oryctes rhinoceros. J. Ilmu-ilmu Pertanian. 4(1): 47-54.

Indriyati. 2009. Virulensi jamur Entomopatogen Beauveria bassiana ( Balsamo) Vuillemin Terhadap Kutu Daun (Aphis spp.) dan Kepik Hijau ( Nezara Viridula). J. HPT Tropika. 9( 2):92-98.

Nuraida, dan A. Hasyim. 2009. Isolasi, identifikasi, dan karakterisasi jamur entomopatogen dari rizosfir pertanaman kubis. J. Hort. 19(4): 419-432.

Prayogo.Y, dan Suharsono. 2005. Optimalisasi pengendalian hama pengisap polong kedelai (Riptortus linnearis) dengan cendawan entomopatogen Verticillium lecanii. J. Litbang Pertanian. 24(4): 123-130. 
Prayogo, Y., W. Tengkano, dan Marwoto. 2005. Prospek cendawan entomopatogen Metarhizium anisopliae untuk mengendalikan ulat grayak Spodoptera litura pada kedelai. J. Litbang Pertanian. 24(1): 19-26.

Purnomo, T.N. Aeny, dan Y. Fitriana. 2012. Pembuatan dan aplikasi formulasi kering tiga jenis agensia hayati untuk mengendalikan hama pencucuk buah dan penyakit busuk buah kakao. Laporan penelitian hibah bersaing. Universitas Lampung. Bandar Lampung.
Rustama, M. M., Melanie., dan B. Irawan. 2008. Patogenisitas jamur entomopatogen Metarhizium anisopliae terhadap Crocidolomia pavonana dalam kegiatan studi pengendalian hama terpadu tanaman kubis dengan menggunakan agensia hayati. Laporan penelitian. Universitas Padjadjaran. Jawa Barat. Diakses tanggal 15 Februari 2013.

Suwahyono. 2010. Cara Membuat dan Petunjuk Penggunaan Biopestisida. Penebar Swadaya. Jakarta 